\title{
Institutional distance and knowledge acquisition in international buyer-supplier relationships: The moderating role of trust
}

\author{
Mia Hsiao-Wen Ho ${ }^{1}$ - Pervez N. Ghauri ${ }^{2}$. \\ Jorma A. Larimo ${ }^{3}$ \\ Published online: 13 July 2017 \\ (C) The Author(s) 2017. This article is an open access publication
}

\begin{abstract}
Institutional distance can generate expanded opportunities for multinational firms to facilitate learning and responsiveness. However, such distance can also create obstacles regarding knowledge transfer and integration. A theoretical puzzle concerns the mechanisms and conditions in which international buyers and suppliers can overcome institutional distance and acquire new knowledge. We develop an integrative moderated-mediation model in which institutional distance prevents parties from accessing knowledge but, when knowledge is obtained and mutual trust is developed, it promotes cross-border knowledge acquisition in international buyer-supplier exchange, particularly between international firms and firms from the Asia Pacific region. These findings indicate that firms can overcome the challenges of regulative and cognitive distance and facilitate access to knowledge and knowledge acquisition when they are able to develop and cultivate relationships of mutual trust with foreign partners. While normative distance may create learning incentives and opportunities in international buyer-supplier relationships, its impacts on knowledge accessibility and acquisition are insignificant.
\end{abstract}

Pervez N. Ghauri

p.ghauri@bham.ac.uk

Mia Hsiao-Wen Ho

mia.hohw@mail.nsysu.edu.tw

Jorma A. Larimo

jorma.1arimo@uwasa.fi

1 Department of Business Management, College of Management, National Sun Yat-sen University, 70 Lienhai Rd, Kaohsiung 80424, Taiwan

2 Birmingham Business School, University of Birmingham, Edgbaston Park Road, Birmingham B15 2YT, UK

3 University of Vaasa, PO Box 700, 65101 Vaasa, Finland 
Keywords Cross-border knowledge acquisition · Access to knowledge $\cdot$ Institutional distance $\cdot$ Buyer-supplier exchange $\cdot$ Trust

Multinational firms are constantly searching for ways to develop and enhance their knowledge base because the possession of superior knowledge has the potential to generate a competitively advantageous position in the global marketplace. Most prior studies argue that high levels of knowledge should be better exploited in an unstable and volatile environment (Kogut \& Zander, 1992; Xu, Huang, \& Gao, 2010). For instance, in the information and communication technology (ICT) industries - which are characterized by relatively short product life cycles-firms are forced to make a strategic decision to either create valuable knowledge on their own or to acquire this knowledge from external partners, due to the knowledge-based competition. When engaged in knowledge transfer processes with external partners, firms also have to make strategic decisions, as they are more exposed to the risk of leaking knowledge or participating in undesirable learning races (Gomes, Barnes, \& Mahmood, 2016; Hamel, 1991).

International knowledge transfer involves, inter alia, accessing and acquiring knowledge that has been exchanged between firms across national boundaries. How firms gain access to, and acquire knowledge from, foreign partners with whom they participate in commercial exchange is confined by environmental uncertainty. This is particularly so with regards to the impact of institutional constraints on contractual relationships between international buyers and sellers - a significant subject of inquiry in the fields of strategy and international business literature. While governance mechanisms are vital in managing collaborative relationships, knowledge transfer is predominantly a social process (Kogut \& Zander, 1992; Yli-Renko, Autio, \& Sapienza, 2001) that is said to be complete when learning takes place and when the recipient firm understands the intricacies and implications associated with that knowledge and is in a position to apply it (Ko, Kirsch, \& King, 2005).

We propose, therefore, that partners' willingness and capacity to allow access to each other's knowledge bases are key intervening mechanisms that may facilitate or undermine the processes of cross-border knowledge acquisition. Even if knowledge is transferred from one firm to the other with open access, however, there can be no guarantees that the knowledge is fully acquired as expected. Acquiring knowledge in international buyer-supplier relationships where the institutional distance context is prevalent is a particularly complex challenge for multinational firms, yet the explanations of how and why cross-border knowledge acquisition between institutionallydistant partners might fail are not substantial. The limited understanding of this subject results mainly from the general neglect of contextual factors that condition the effectiveness of international knowledge acquisition in the prior literature (Liu \& Giroud, 2016).

Multinational firms operate on a worldwide basis and effective knowledge acquisition across countries has proven challenging due to temporal, spatial, and institutional distance (Javidan, Stahl, Brodbeck, \& Wilderom, 2005; Li \& Scullion, 2006). While the influence of time and space distance on international knowledge acquisition can be offset by ICT, that of institutional distance, which deals with country-specific dimensions of contextual variation (such as regulatory and legal factors, cultural norms and cognitive beliefs) may be difficult to tackle due to "liability of foreignness," which 
poses social costs of doing businesses in international markets (Puffer, McCarthy, Jaeger, \& Dunlap, 2013). This study thus attempts to extend existing research on knowledge acquisition in international business exchange by looking into the context-specific barriers derived from institutional distance between foreign and host country partners in Asia Pacific regions.

Drawing on the institution-based view (Peng, Sun, Pinkham, \& Chen, 2009), we perceive institutions to be no longer silent but rather influential factors in explaining the performance of international collaborations, because they "directly determine what arrows a firm has in its quiver as it struggles to formulate and implement strategy" (Ingram \& Silverman, 2002: 20). As such, we develop and examine an integrative moderated-mediation model positing regulatory, normative, and cognitive pillars of institutional distance as focal antecedents of knowledge acquisition through the mediating impact of access to knowledge in international buyer-supplier relationships. Specifically, we argue that institutional distance is likely to inhibit knowledge acquisition because of the decreased levels of willingness to transfer knowledge from one partner to the other, but also due to contextual factors that create complexity and ambiguity, undermining the capacity of international buyers and suppliers to source new knowledge bases (Xu et al., 2010).

Illuminating the importance of institutional factors is essential to understand fully the potential constraints and opportunities they create for firms, and the strategic orientations and actions firms navigate, respond and adapt to within the heterogeneous institutional environments of emerging economies. With this in mind, we synthesize the relational view (Dyer \& Singh, 1998) with the institution-based view (Peng et al., 2009) in a theoretical framework, arguing that the construction and maintenance of a trustworthy relationship in international business exchanges enable firms to overcome institutional constraints, which often requires efforts and sacrifices from both parties.

Mutual trust helps develop better understanding and appreciation between partners. For example, if one partner allows the other party access to knowledge, the recipient firm may not fully understand and thus underutilize the transferred knowledge (Park \& Ghauri, 2011), not only because the knowledge is context- and firm-specific but also because the recipient does not value the knowledge as the transferor does. Furthermore, mutual trust builds belief in both partners that neither of them would act opportunistically (Gulati, 1995; Lane, Salk, \& Lyles, 2001) by negatively exploiting the acquired knowledge to the determent of the other.

Accordingly, in the model we consider mutual trust to be a key moderator along with the knowledge acquisition process: on the one hand, it is said to lessen the noxious influences of institutional distance on the access to knowledge; on the other hand, it can strengthen the positive feedback of knowledge acquisition from open access to the partner's knowledge base. In so doing, our research contributes to the international business and strategy literature by unraveling the complex processes and conditions in which institutional distance results in cross-border knowledge acquisition, and by offering corresponding relational strategies to better manage knowledge acquisition processes between institutionally-distant partners in international business exchanges.

We test our model using survey data from ICT manufacturing companies in Taiwan and their foreign partners in 29 countries. The ICT industry is a global one and is very important to the Taiwanese economy, accounting for over 50\% of Taiwan's GDP in manufacturing since 2006 and 24\% of the country's total export activities in 2011 
(Chiang, 2012). Consequently, this setting offers a rich context as Taiwanese firms engage in business exchanges with a wide variety of international companies.

\section{Theory and hypotheses}

\section{Institutional distance and access to knowledge}

A large number of studies exist that seek to identify the antecedents and determinants of knowledge acquisition both within and across organizational boundaries. These factors, as compiled by Van Wijk, Jansen, and Lyles (2008), include knowledge, organizational, and dyad- or network-level characteristics. The contributions of these studies, however, become less significant when explaining the complex nature of knowledge acquisition at the international level, given the inherent challenges which result from contextual variation between partners. An obvious contextual challenge of knowledge acquisition in international buyer-supplier relationships concerns the institutional distance between home and host countries. Institutions are defined as "the human devised constraints that structure human interactions" (North, 1990: 3). They embody "rules of the game" (North, 1990: 3) and therefore exercise constraint and control; they enable economic activities and affect both domestic and foreign firms' behaviors in various ways in a given country. While the collaborative knowledge being transferred and acquired in international business exchanges is governed by certain forms of contract or agreement, incompatible institutional frameworks (i.e., different levels of legal enforcements on intellectual property rights and setting disputes, diverse cultural norms and cognitive beliefs) between host and home country partners may lead to unsuccessful knowledge acquisition, as firms may take greater precautions to safeguard their knowledge base, limiting their partners' access to the knowledge.

Unlike most previous studies that simplify institutional distance as a single variable hindering assorted cross-border activities, such as foreign entry mode choices (Yiu \& Makino, 2002), partner selection of international alliances (Li \& Ferreira, 2008), and the performance of cross-border acquisitions (Dikova, Sahib, \& van Witteloostuijn, 2010), we highlight the formative nature of institutional distance in this study, because it is measured by "the extent of similarity or dissimilarity between the regulatory, normative, and cognitive institutions of two countries" (Kostova, 1996). Regulatory institutions refer to political environments, including laws and regulations that construct and constitute the grounds of organizational and industrial actions and ensure stability and order in societies (North, 1990; Scott \& Meyer, 1994). Normative institutions represent the shared understanding and meaning or the "logic of appropriateness" (March, 1981) that is embedded in the forms of national cultures, values, norms and belief systems. Finally, cognitive institutions are "the widely shared cognitive structures by which actors of a given organizational field or societal entity interpret and make sense of their world" (Yiu \& Makino, 2002: 671). Firms can only conform to social expectations when they are rewarded for doing so through increased legitimacy, resources and organizational success or survival (Baum \& Oliver, 1991; DiMaggio \& Powell, 1983). The distinction between the three dimensional factors of institutional distance contributes to expanding the institutional theory in the international business and strategy fields, as it could help us to understand the individual impacts of 
regulatory, normative, and cognitive distances on the process of international knowledge acquisition and generate the corresponding strategies.

In fact, institutional theorists have long been concerned with the negative influences of heterogeneous institutional environments on doing businesses across countries. Unfortunately, attempts to address such distance effects on knowledge acquisition in international business exchanges are rare. To address this unresolved issue in the literature, we therefore posit institutional distance as a key contextual determinant of cross-border knowledge acquisition in international buyer-supplier exchanges. Specifically, we propose that if a firm acquires knowledge from its institutionallydistant partner, its access to the partner's knowledge bases would be highly restricted. From the recipient's point of view, access to knowledge and its acquisition entails complications since a partner's knowledge is often context-specific and exploratory in nature. While ICT can help overcome the difficulty associated with geographical distance, issues related to institutional distance are more complex and resolving them poses greater challenges. This is because institutional distance issues are inherently embedded in nations' social structures and contexts that are rigid and unyielding (William \& Lee, 2016).

In the context of international buyer-supplier relationships, institutional distance between home and host country partners may create new challenges and greater complexity in relation to cross-border communication and coordination, design of compatible knowledge transfer routines and systems, and development of common managerial approaches (Peltokorpi, 2017; Simonin, 1999a, 1999b). Institutional distance can be expected to increase the ambiguity of knowledge contents and decrease the flows of information sharing and exchanges (Lyles \& Salk, 1996). This limits both the recipient's capacity to fully access the knowledge base and the identification of some of the relevant factors and knowledge components that reside in the partnering firm. Institutional distance between firms can also lead to concerns over potential opportunistic behavior, as well as to misunderstanding and conflict — not on the content of knowledge but rather on the efforts devoted by the partners to ease the access to the knowledge bases. Thus:

Hypothesis 1 Regulatory, normative, and cognitive aspects of institutional distance negatively affect access to knowledge in an international business exchange.

\section{Access to knowledge and knowledge acquisition}

In the international business and strategy literature, there is increasing recognition that knowledge is an important factor strengthening multinational firms' competiveness (Johanson \& Vahlne, 2009; Park, 2008). Cross-border knowledge acquisition is of particular importance for organizational renewal and sustainable competitive advantage, as firms constantly compete for knowledge resources and often utilize their abilities to extract such valuable resources externally via international networks. As the acquisition of new knowledge from external partners is the lifeblood of experimentation, innovation and change for firms (Inkpen, 2000), firms can gain access to their partners' broad knowledge-based resources and capabilities by forming international collaborative relationships.

Although knowledge transfer through international networks has become a shot gun approach for a firm to acquire knowledge that it could not easily develop within its 
confines (Narteh, 2008), intrinsic competition between collaborative partners becomes an inevitable dilemma in knowledge transfer processes, in that one partner might opportunistically take advantage of the cooperation to learn about the other partner's knowledge, and in some extreme cases, to acquire technological secrets without the other's consent (Khanna, Gulati, \& Nohria, 1998; Muthusamy \& White, 2005). Much prior research has emphasized the cynical role played by opportunism in the acquisition of new knowledge because it prevents firms from effectively and efficiently learning from their external partners (e.g., Ding, Huang, \& Liu, 2012; McEvily, Das, \& McCabe, 2000).

A fundamental challenge concerning international collaborations is the inter-firm asymmetry of knowledge demand and supply. That is, a firm's accessibility to its partner's knowledge base is correspondingly asymmetrical (Nielsen, 2005). Accessibility is crucial in the knowledge acquisition process because knowledge must be accessible before it can be acquired (Kwan \& Cheung, 2006). Knowledge acquisition is inter alia a function of how easily it can be accessed (Hamel, Doz, \& Prahalad, 1989). Ease of accessibility is determined by the nature of the knowledge: whether knowledge can be codified and transmitted in a formal and systematic way (explicit or tacit) (Lee, Chang, Liu, \& Yang, 2007; Nonaka \& Takeuchi, 1995). It has been argued that articulable knowledge is transferable with less effort than less-articulable knowledge (Cummings \& Teng, 2003). However, even if stocks of knowledge mainly comprise codified documents and information, such as patents or product formulas, explicit knowledge must rely on being tacitly understood and applied (Polanyi, 1966).

Differences in institutional frameworks and developments of the countries from where partner firms originate could become the sources of knowledge transfer and learning due to the potentially useful diversity of practices, beliefs and values. However, in the context of international business exchanges, the nature of the knowledge can become ambiguous and uncertain if it is shared and learned between institutionally-distant partners, not only because partners from different institutional environments may hold incompatible views on how knowledge is transferred and acquired but also because of the intrinsic competition between partners over key knowledge-based resources in the collaboration. From a competitive perspective, a loss of knowledge by the partner via asymmetrical learning could result in the creation of a new or stronger competitor (Inkpen, 2000; Tsang, 1999). In an empirical study examining the underlying reasons for the instability of international joint ventures, Inkpen and Beamish (1997) found that a joint venture would become less stable if one partner accumulates the key knowledge-based resources from the other.

Tellingly, cross-border knowledge transfer creates certain conditions that lead partner firms to decide what extent of their knowledge base should remain within the private domains and how to ensure that this is securely protected so as to keep the longterm viability of the partnerships (Norman, 2002). Prior studies have advocated that knowledge protection is essential for the stability of some cross-border collaborations (e.g., Lee et al., 2007; Norman, 2002), nevertheless, we propose that a high level of knowledge protection, due to the perceived opportunism of the institutionally-distant partner, could cause negative effects on the learning process. In an empirical research on intellectual capital protection in international alliances, Baughn, Denekamp, Stevens, and Osborn (1997) discovered that a firm's over-reliance on structural and 
contractual means of protection very often would fail to effectively regulate the flows of knowledge to its partner.

Grounding Lyles and Salk's (1996) and Simonin's (1999a, 1999b) statements, we argue that the excessive knowledge protection leads to uncertainties and conflicts in cross-border collaborations and further limits knowledge acquisition. However, in this study we highlight that such restrictive access to the knowledge bases of firms mainly results from the large institutional distance between partners. Given that a firm may not be fully aware of the level of its partner's protective behavior, owing to the inherent information asymmetry in knowledge transfer and learning processes, it can sense, perceive, and experience the difficulties in accessing its partner's knowledge base. In other words, if there is no restriction on the access to knowledge (e.g., the open and flexible developments in knowledge infrastructure and the absence of knowledge protection), due to the negligence of opportunistic concern in collaborating with the partner from a similar institutional framework, knowledge acquisition can be correspondingly enhanced. This not only enriches the current understanding of the antecedents of knowledge protection in international business exchanges in the literature but also implies the crucial mediating role played by access to knowledge in the relationship between institutional distance and international knowledge acquisition. Thus:

Hypothesis 2 Access to knowledge positively affects knowledge acquisition in an international business exchange.

Hypothesis 3 Access to knowledge mediates the impacts of regulatory, normative, and cognitive aspects of institutional distance on knowledge acquisition in an international business exchange.

\section{The moderating role of mutual trust}

Trust has been recognized as a crucial factor in social exchanges that affects organizational effectiveness, performance and efficiency (Sako, 1998; Williams \& Du, 2014). It is defined as "the willingness of a party to be vulnerable to the actions of another party based on the expectation that the other party will perform a particular action important to the trustor, irrespective of the ability to monitor or control the other party" (Mayer, Davis, \& Schoorman, 1995: 712). International business scholars have adopted the essence of this definition and conceptualize trust in an international business context as the expectation that a partner firm can be relied upon to carry out the international business exchange relationship, will bring resources that are necessary to do so, and will behave honorably to achieve mutual objectives and interests (Boersma, Buckley, \& Ghauri, 2003).

Inter-organizational relationships are channels through which firms transfer and acquire knowledge (Huber, 1991). Trust in alliances is a necessary condition if cooperative behavior involves sharing innovative knowledge, information, and skills (Brunetto \& Farr-Wharton, 2007). Knowledge flows best through trusting communities and it is believed that social relationships facilitate the transfer of valuable resourcesespecially information and knowledge - by acting as a lubricant (Adler, 2001). A lack of trust in alliances often results in low joint performances. The effectiveness of interorganizational exchange thus depends on the quality of relationships that partners develop (Larsson, 1992; Porras, Clegg, \& Crawford, 2004). 
International business researchers have emphasized the importance of trust for successful knowledge acquisition especially in Asia Pacific regions. For instance, Park, Giroud, Mirza, and Whitelock (2008) argued that trust between foreign and local parents is positively associated with a Korean international joint venture's knowledge acquisition and performance. More recently, Liu, Ghauri, and Sinkovics (2010) indicate that relational capital, which is defined as a relational rent generated in an exchange relationship, which cannot be generated by either firm in isolation, has a positive effect on knowledge acquisition in Taiwan-based international strategic alliances. Williams and Du (2014) found that innovative performance of multinational enterprise subsidiaries in China is positively influenced by trusting relationships with local external partners.

Given a wide notion of the positive impact of trust on cross-border knowledge acquisition in the prior literature, however, an unresolved issue is that successful knowledge acquisition cannot always be guaranteed, even if a firm possesses a high level of trust toward its partner. This may be because its partner has no faith in trusting the firm in exploiting the transferred knowledge, and thus limits the firm's access to its knowledge bases. The lack of mutual trust in knowledge transfer and learning processes could be harmful to the cooperative performance, as the level of mutual trust in alliances determine the partners' willingness to share knowledge whether confidential or commercially sensitive in nature (Brunetto \& Farr-Wharton, 2007). Mutual trust is a reflection of both parties' predisposition towards trusting and their beliefs about each other. It is considered to be an important control mechanism (Williamson, 1993) within alliances to mitigate risk of perceived opportunism and withholding knowledge between institution-distant partners, ensuring that similar cooperative goals are being pursued and further facilitates the knowledge acquisition process through a shared understanding of how much knowledge can be accessed in the international business exchange contexts.

As we hypothesized earlier that access to knowledge is a key variable mediating the negative impact of institutional distance on international knowledge acquisition, we thereby posit mutual trust as a two-stage moderator influencing international knowledge acquisition processes. In the first stage, we expect mutual trust to enable firms to work out uncertainties and challenges while cooperating with institutionally-distant partners, and to overcome conflicts and reduce the chances that they would be further escalated in accessing partners' knowledge bases (Nguyen, Weinstein, \& Meyer, 2005; Wang \& $\mathrm{Wu}, 2016)$. Mutual trust in a partnership is a combination of the bonds developed and the expectations of the relationship (Brunetto \& Farr-Wharton, 2007), so that it develops in response to outcomes of risk-taking and adaptation for environmental uncertainties. In turn, mutual trust is important for realizing accessibility to knowledge acquisition.

Even if a partner gains access to the other's knowledge base, however, it may not be fully understood and can potentially be misinterpreted. In the second stage, we propose that international business exchanges with a high level of mutual trust between partners can attain better learning outcomes by the increased knowledge acquisition, in that it can help firms to cope with causal ambiguity in accessing others' knowledge bases and to voice and seek professional help from their partners. For example, in trusting relationships, firms are more willing to take actions in communication or information exchanges (Ring \& Van de Ven, 1994; Svejenova, 2006), which are essential for 
knowledge acquisition. Overall, we expect mutual trust to facilitate inter-firm communication and knowledge sharing design so that maximum benefits can be derived from synergies while managing perceived differences from heterogeneous institutional environments of alliance partners.

In other words, with higher level of mutual trust in alliances, partner firms would be able to alleviate their perceived opportunism towards knowledge transfer and sharing derived from institutional distance and be willing to open up much freer access of their knowledge bases to each other, leading to enhanced knowledge acquisition outcomes due to positive, close interactions and communications between partners along with the collaborative processes. Partners with high level of mutual trust can work on coinciding their cooperative objectives to develop synergies while managing perceived opportunism derived from environmental uncertainties of institutional distance, disengaging their protection on the imperative knowledge contributing to the alliance success. Thus:

Hypothesis 4 The strength of the mediated relationship between regulatory, normative, and cognitive aspects of institutional distance and knowledge acquisition through access to knowledge will vary depending on the extent of mutual trust in an international business exchange; when partners develop a high level of mutual trust (a) the negative influences of regulatory, normative, and cognitive distances on access to knowledge will be lessened, and (b) the positive influence of access to knowledge on knowledge acquisition will be strengthened.

\section{Methods}

\section{Participants and procedures}

We employed a cross-sectional survey to collect primary data from both web-based and mail questionnaires. To avoid the common method bias, we collected secondary data from the Global Information Technology Report 2010-2011 (Dutta \& Mia, 2011) while Hofstede's (2011) cultural dimension indices were used to examine the issue of international knowledge acquisition. We focused our analysis on Taiwanese ICT manufacturers who have business exchange relationships with foreign partners, as they are relatively R\&D-intensive across all firm sizes. By definition, ICT manufacturing products include laptops, personal computers, flat panel displays, modems, motherboards, and other electronic components and products (Dahl \& Lopez-Claros, 2006). We identified 2559 Taiwan-based ICT manufacturers from the Ministry of Economic Affairs database in Taiwan, which is an official database providing a user-friendly interface containing industry classifications, company IDs, main products/services, number of employees, addresses, websites, telephone and fax numbers. To enhance the reliability of the sample list, we further utilized a cross checking approach which involved investigating companies' websites, emailing or phoning contacts to finalize an eligible sample set of 671 Taiwan-based ICT manufacturers with knowledge acquisition activities through international buyer-supplier relationships.

Following Dillman, Smyth, and Christian's (2009) tailored design method, we collected survey data in two steps: web-based questionnaires via emailing to the sampling firms with follow-ups every couple of weeks from mid-June to the end of 
July 2010; we also sent out questionnaires to non-respondents with one telephone follow-up from early August to mid-September 2010. The target respondents were senior management of the sample firms, such as R\&D managers, CEOs and international project leaders, who are most knowledgeable about cross-border knowledge acquisition. The valid response rate was $41.90 \%$. We tested for potential bias between responding and non-responding firms (in terms of the firms' product categories, number of employees), as well as for early and late respondents and found no statistically significant differences $(p>.10)$.

\section{Measures and control variables}

In parallel with prior studies on institutional distance (e.g., Gaur \& Lu, 2007; Ionascu, Meyer, \& Erstin, 2004), we adopted 7-item and 5-item scale measures from The Global Information Technology Report 2010-2011 (Dutta \& Mia, 2011) to reflect the regulatory and cognitive distances, respectively; we also used 6-item scale measures from Hofstede's (2011) cultural dimension indicators to represent normative distance. Regulatory institutions lay out the ground rules for doing business, reflecting the laws and regulations of a country that influence business strategies and operations; normative institutions consist of beliefs, values, and norms that define expected behavior in a society; and cognitive institutions rest on the cognitive structures, widely shared social knowledge, frames, routines and scripts, embedded in a society (Ionascu et al., 2004). Accordingly, the selection of the appropriate measures is based on the relevance to the research scope of ICT industries in Taiwan. Due to the composite scales of the collected data, the calculation of the values for institutional distance measures is adjusted by the variance explained of each measure and the formula is presented below:

$$
I D_{t f}=\sum_{i=1}^{n}\left[\left(I_{t}-I_{f}\right)^{2} / V_{I}\right] / n
$$

where $I D_{t f}$ refers to the institutional distance between Taiwan $(t)$ and the foreign country $(f) ; I_{t}$ refers to the institutional distance indicator for Taiwan; $I_{f}$ refers to the institutional distance indicator for the foreign country; $V_{I}$ is the variance of indicator $I$; and $n$ is the number of indicators.

The formula design originates from Kogut and Singh's (1988) research on cultural distance, in which the authors correct the variance to impose certain weights on indicators in the composite index of Hofstede's cultural dimensions, and is popularly applied by subsequent research on the examination of cultural or institutional differences in international contexts (e.g., Gaur \& Lu, 2007; Morosini, Shane, \& Singh, 1998).

Apart from the measures of institutional distance, we used questionnaire items to examine the measures of access to knowledge, knowledge acquisition, and trust by fivepoint Likert scales, ranging from " $1=$ strongly disagree/very low" to " $5=$ strongly agree/ very high" to allow for consistency in the response pattern. We measure access to knowledge using two Likert-type scale items adapted from Nielsen and Nielsen's (2009) and Jensen, van den Bosch, and Volberda's (2005) studies that capture the extent to which the partner restricts your firm's access to the knowledge bases and the extent to which the partner's cooperative structure in knowledge transfer and learning is open and flexible.

Following Lane et al.'s (2001) and Lyles and Salk's (1996) empirical studies, we measure knowledge acquisition by a specific set of knowledge pool related to the 
business exchanges, including the extent of the new technological, marketing, managerial, manufacturing, and product development techniques/expertise acquired from the international buyer/supplier. Based on Nielsen and Nielsen's (2009) notion that both partners' perceptions are symmetrically important in reflecting facets of relational exchanges in crossborder collaborations, we applied mutual-dimensional items to assess mutual trust as the extent to which partners interact and communicate with each other in a respectful manner (Cousins, Handfield, Lawson, \& Petersen, 2006; Liu et al., 2010).

We controlled for the international buyer-supplier relationship duration by measuring the number of years the partners have been collaborating. This is because the longer partners are in a business exchange relationship, the more committed they may be to further engage in knowledge transfer and learning processes (Simonin, 2004), which in turn may increase international knowledge acquisition. We also controlled for the prior experience of international business exchange relationships by using a dummy variable to examine if the firm has experience of collaborating with the same country-of-origin partner(s) before $(0=$ no; $1=$ yes $)$. This is because previous studies have shown that firms with prior understandings about their partners' skills and capabilities are more likely to block the pressures of uncertainty in relationships (Inkpen, 2008), which may result in better collaborative outcomes in terms of increased international knowledge acquisition. By a preliminary analysis of variance (ANOVA) on the proposed control variables, we found that alliance duration and prior experience have no significant effects on international knowledge acquisition in this study $(p>.05)$.

\section{Analysis and results}

\section{Preliminary analysis}

We conducted a confirmatory factor analysis on the six measurement scales (i.e., regulatory, normative, cognitive distances, access to knowledge, trust, and knowledge acquisition) to examine convergent and discriminate validity. Results showed that the proposed measurement models offered a good fit to the data, $\chi^{2}(112$, $N=281)=319.25, p<.05, \mathrm{NFI}=.94, \mathrm{CFI}=.93, \mathrm{SRMR}=.04$. Table 1 presents descriptive statistics and correlations for all constructs including control variables,

Table 1 Means, standard deviations and correlations

\begin{tabular}{|c|c|c|c|c|c|c|c|c|c|c|}
\hline Variables & Mean & $\mathrm{SD}$ & $\mathrm{RD}$ & ND & $\mathrm{CD}$ & ATK & MT & KA & $\mathrm{AD}$ & PAE \\
\hline Regulatory distance (RD) & 1.38 & 1.52 & - & & & & & & & \\
\hline Normative distance (ND) & 2.22 & .99 & .05 & - & & & & & & \\
\hline Cognitive distance $(\mathrm{CD})$ & 1.13 & 2.31 & .09 & .04 & - & & & & & \\
\hline Access to knowledge (ATK) & 2.25 & .72 & -.15 & -.02 & -.18 & & & & & \\
\hline Mutual trust (MT) & 3.98 & .73 & -.08 & -.07 & -.10 & .07 & 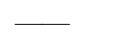 & & & \\
\hline Knowledge acquisition (KA) & 3.72 & .60 & -.07 & -.05 & -.06 & .25 & .37 & & & \\
\hline Alliance duration (AD) & 6.34 & 5.37 & -.02 & -.01 & -.02 & .01 & .08 & .03 & - & \\
\hline Prior alliance eperience (PAE) & .31 & .50 & -.03 & -.06 & -.04 & .06 & .09 & .01 & .07 & - \\
\hline
\end{tabular}


alliance duration and prior alliance experience, which were not correlated with any of the study variables. Table 2 indicates that all factor loadings were statistically significant with standardized loadings ranging from .63 to $.90(p<.05)$ and all variables have acceptable internal consistency alphas of above .70. Model fit was also significantly better for the six-factor model compared with a fourfactor model that combined regulatory, normative and cognitive distances into one factor, $\Delta \chi^{2}(59, N=281)=630.05, p<.05$, and a single-factor model, $\Delta \chi^{2}(8, N=281)=1395.84, p<.05$. A significantly lower $\chi^{2}$ value for the

Table 2 Confirmatory factor analysis on measurement models

\begin{tabular}{lll}
\hline Items & $\lambda$-value $\alpha$ \\
\hline
\end{tabular}

Knowledge acquisition (KA): Adapted from Liu et al. (2010); Tsang, Nguyen, and Erramilli (2004)

To what extent does your firm acquire the following knowledge from the foreign partner?

KA1: New technological expertise

KA2: New product development expertise

KA3: New manufacturing expertise

KA4: New marketing expertise

KA5: New managerial expertise

Regulatory distance: Adapted from Chao and Kumar (2010); Gaur and Lu (2007)

RD1: Laws relating to information and communication technology

RD2: Intellectual property protection

RD3: Property rights

RD4: Effectiveness of law making bodies

RD5: Judicial independence

RD6: Efficiency of legal framework in settling disputes

RD7: Efficiency of legal framework in challenging regulations

Normative distance (ND): Adapted from Manev and Stevenson (2001);

Tihanyi, Griffith, and Russell (2005)

ND1: Power distance

ND2: Individualism

ND3: Uncertainty avoidance

ND4: Long-term orientation

ND5: Indulgence versus restraint

ND6: Masculinity

Cognitive Distance (CD): Adapted from Nooteboom, Van Haverbeke, Duysters, Gilsing, and Van den Oord (2007)

CD1: Company spending on research and development

CD2: Firm-level technology absorption

CD3: Capacity for innovation

CD4: Impact of information and communication technology on new products and services

CD5: Impact of information and communication technology on new organizational models

$\lambda=$ factor loading; $\alpha=$ Cronbach's alpha 
unconstrained models indicated that the proposed constructs exhibit discriminant validity (Bagozzi \& Phillips, 1982).

\section{Test of hypotheses}

We tested our hypotheses by path analytic procedures (Edwards \& Lambert, 2007) and bootstrapping approach to examine the significance of indirect effects (Shrout \& Bolger, 2002). We used an SPSS macro (Hayes, 2013) to assess both mediation and moderated mediation models developed in this study. The statistical results derived from mediation model analyses showed that regulatory and cognitive distances are negatively related to access to knowledge $(\beta=-.14 /-.18, p<.05)$ and access to knowledge is positively associated with knowledge acquisition $(\beta=.26, p<.01)$, yet the association between normative distance and access to knowledge is insignificant $(\beta=-.08, p>.05)$. Results also revealed that the indirect effects of regulatory and cognitive distances on knowledge acquisition were significant $(\beta=-.04 /-.05, p<.05)$. These indicate partial rejection of Hypotheses 1 and 3, but provide strong empirical evidence in support of Hypothesis 2.

Tables 3 and 4 indicate results from the moderated mediation model. It shows that the interactions of regulatory and cognitive distances with mutual trust were significant in predicting access to knowledge $(\beta=.17 / .18, p<.01)$, but the interaction of normative distance with mutual trust did not predict access to knowledge $(\beta=.02$, $p>.05$ ). Additionally, the interaction of access to knowledge and mutual trust was significant in predicting knowledge acquisition $(\beta=.11, p<.05)$. Figure 1 shows that large regulatory and cognitive distances were associated with decreased access to knowledge for partners with low mutual trust (Simple slope $=-.30 /-.33, p<.01$ ). However, regulatory and cognitive distances were not associated with access to

Table 3 Moderated regression analyses predicting access to knowledge and knowledge acquisition

\begin{tabular}{|c|c|c|c|c|c|c|}
\hline \multirow[t]{2}{*}{ Variable } & \multicolumn{3}{|c|}{$\begin{array}{l}\text { First stage dependent } \\
\text { variable = access to knowledge }\end{array}$} & \multicolumn{3}{|c|}{$\begin{array}{l}\text { Second stage dependent } \\
\text { variable = knowledge acquisition }\end{array}$} \\
\hline & $\beta$ & SE & $t$ & $\beta$ & SE & $t$ \\
\hline Regulatory distance & -.14 & .09 & $2.15^{*}$ & -.14 & .07 & $2.14^{*}$ \\
\hline Normative distance & -.08 & .08 & .99 & -.08 & .05 & 1.25 \\
\hline Cognitive distance & -.18 & .07 & $2.38^{*}$ & -.18 & .07 & $2.37^{*}$ \\
\hline Trust & .32 & .06 & $5.09^{* *}$ & .32 & .06 & $4.88^{* *}$ \\
\hline Regulatory distance $\times$ Trust & .17 & .05 & $2.93^{* * *}$ & .17 & .07 & $2.81^{* *}$ \\
\hline Normative distance $\times$ Trust & .02 & .07 & .73 & .02 & .05 & .70 \\
\hline Cognitive distance $\times$ Trust & .18 & .06 & $2.97^{*}$ & .18 & .07 & $2.87^{* *}$ \\
\hline Access to knowledge & & & & .26 & .05 & $4.84^{* * *}$ \\
\hline Access to knowledge $\times$ Trust & & & & .11 & .06 & $1.96^{*}$ \\
\hline$F$ & \multicolumn{3}{|c|}{$12.89^{* *}$} & \multicolumn{3}{|c|}{$41.68^{* *}$} \\
\hline$R^{2}$ & \multicolumn{3}{|c|}{.35} & \multicolumn{3}{|c|}{.67} \\
\hline
\end{tabular}

$* p<.05 ; * * p<.01 ; N=281$; standard errors were based on standardized coefficients; values in bold are relevant to tests of hypotheses. 


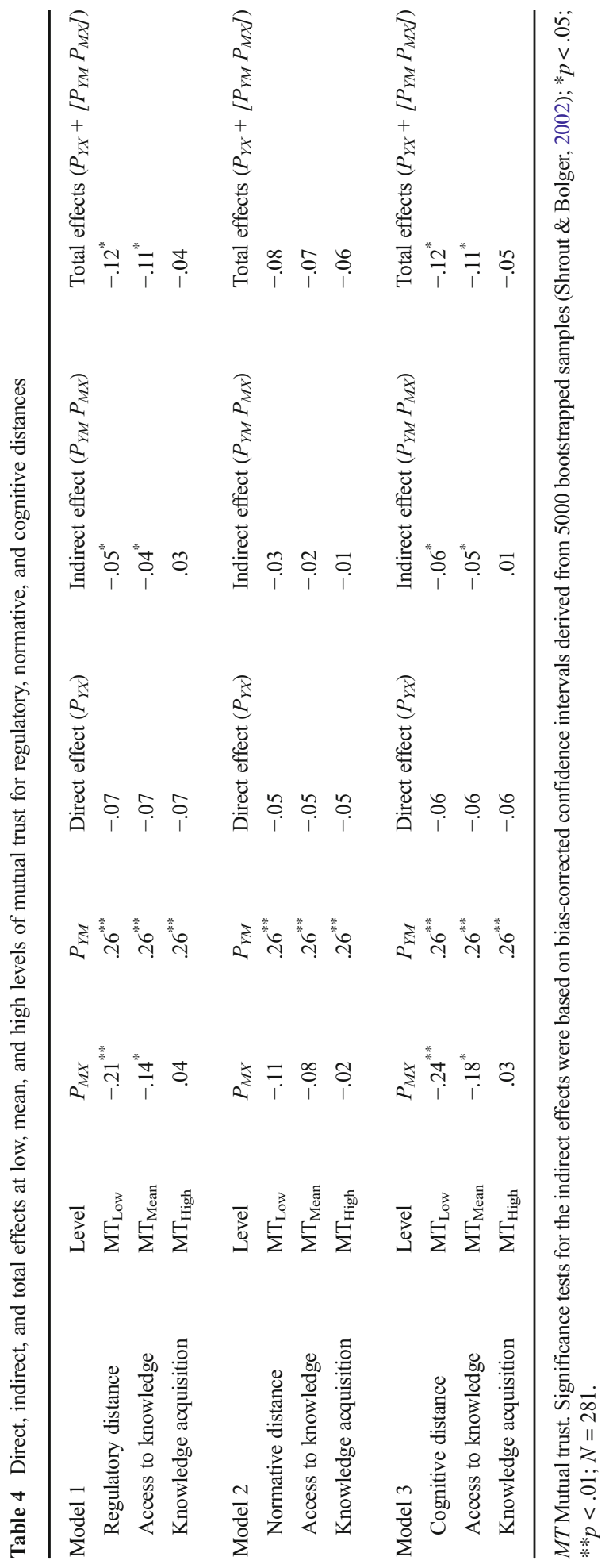




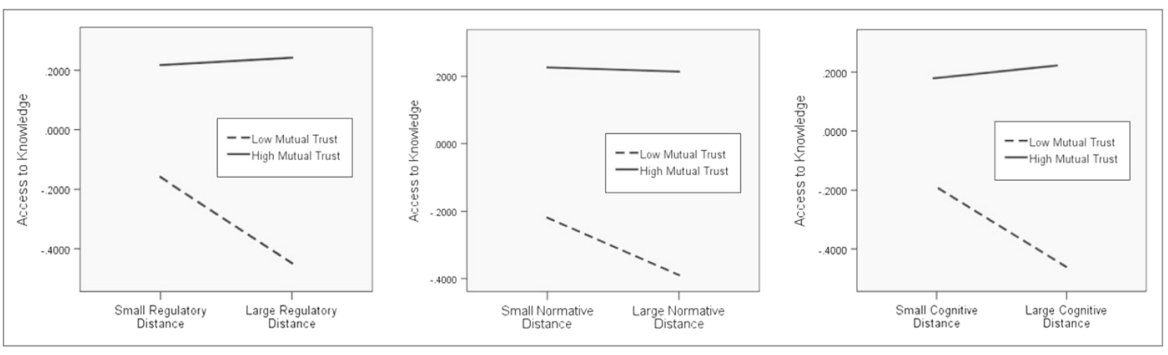

Note: High and low levels of institutional distance and mutual trust represent one standard deviation above and below the mean, respectively.

Fig. 1 Interaction effect of institutional distance and mutual trust on access to knowledge. Note: High and low levels of institutional distance and mutual trust represent one standard deviation above and below the mean, respectively

knowledge for partners with high mutual trust (Simple slope $=.05 / .07, p>.05$ ). Normative distance was not associated with access to knowledge, irrespective of partners with low or high mutual trust (Simple slope $=-.02 /-.10, p>.05$ ).

Further, we examined the conditional indirect effects of regulatory, normative, and cognitive distances on knowledge acquisition through access to knowledge at three values of mutual trust (one standard deviation below the mean, the mean, and 1 standard deviation above the mean). As displayed in Table 4, the conditional indirect effects for regulatory and cognitive distances were significant across low levels of mutual trust $(p<.05)$, yet those were not significant across high levels of mutual trust $(p>.05)$. The conditional indirect effect for normative distance was not significant across all levels of mutual trust $(p>.05)$. Taken together, the results indicated that mutual trust not only moderated the effects of regulatory and cognitive distances on access to knowledge but it also moderated the effect of access to knowledge on knowledge acquisition, leading to partial support of Hypothesis 4a and full support of Hypothesis $4 \mathrm{~b}$. We also conducted the same set of analyses for our mediation and moderated mediation models with control variables (i.e., alliance duration and prior alliance experience) and our results remained the same.

\section{Discussion and conclusion}

\section{Theoretical implications}

This study advances the current understanding of the roles played by institutional distance and mutual trust in the process of knowledge acquisition in international collaborative relationships. We suggest that institutional distance in an international business exchange relationship affects the process of knowledge acquisition through restraining access to knowledge. As regards the institutionally-distant business exchanges, we argue that successful knowledge acquisition is achievable if all partners are willing and able to develop trustworthy relationships with each other, along with the cooperation. To this end, our contribution lies not only in unpacking how institutional distance influences international knowledge acquisition processes, but also in identifying what partner firms can do to overcome, or at least reduce, the negative consequences of institutional distance. Based on an empirical study of 281 international 
business exchange relationships in the Asia Pacific region, our findings support the synthesis of the institution-based view (Peng et al., 2009) with the relational view (Dyer $\&$ Singh, 1998) and have a number of theoretical implications explicated in the following.

First, institutional distance is a critical factor influencing the varied scenarios of cross-border collaborations, in which it matters most to knowledge flows across international contexts. Heterogeneous institutional developments and environments in international alliances may imply huge knowledge gaps between foreign and local partners ( $\mathrm{Li} \&$ Scullion, 2006). Due to the beneficial diversity of practices, beliefs and values residing in and around alliance partners (Sarala \& Vaara, 2010), institutional distance could be one of the potential sources of cross-border knowledge transfer. Notwithstanding, our findings indicate that institutional distance is essentially a key impediment of international knowledge acquisition because on the one hand, it raises the perceived opportunistic behaviors of the partner and on the other hand, it results in difficulties, puzzles, and causal ambiguities associated with knowledge transfer and learning, reflecting the limited access to knowledge. This view parallels $\mathrm{Li}$ and Scullion's (2006) conceptual work that institutional distance affects local knowledge acquisition, transfer and integration in the Chinese business context. Yet we extend the current understanding of the role of institutional distance in international knowledge acquisition by investigating the individual effects of regulatory, normative and cognitive aspects.

By positing the access to knowledge as a crucial mediator in the relation between institutional distance and knowledge acquisition, our findings reveal that regulatory and cognitive distances directly confine the firm's accessibility to its partner's knowledge base, leading to decreased knowledge acquisition, whereas the impact of normative distance on the process of international knowledge acquisition is trivial and seems to be irrelevant. This may be because unlike regulatory and cognitive distances concerning "hard dimensions" of institutions (i.e., legal frameworks and knowledge infrastructure developments at country level) that are usually effortless to recognize and measure, normative distance is rather a "soft" concept dealing with the diversity in social norms, beliefs and cultures across national boundaries that can only be observed through partner interaction. These therefore unpack the reasons why the effects of cultural distance on international knowledge transfer and acquisition have been inconclusive in the international business literature.

Second, mutual trust can be regarded as a form of control in international knowledge acquisition processes. This refers to the extent to which international collaborative partners act on building strong relationships based on mutual trust, irrespective of the contextual challenges resulting from institutional distance. Much of the literature in the fields of knowledge transfer and learning has recognized that unstable relationships emerge between the transferor and the recipient, due to the risk of knowledge loss or the learning race (Hamel, 1991). Although some attempts have been made by researchers to explain the confounding circumstances during knowledge transfer and learning processes, such as "boundary paradox" (Quintas, Lefrere, \& Jones, 1997: 389) and "causal ambiguity paradox" (King \& Zeithaml, 2001: 76), the current understanding of how to ease and control such knowledge-based competition in international contexts is not substantial. 
Given the practical importance of mutual trust between firms, researchers have yet to explore how it facilitates the process of knowledge acquisition in international contexts, in particular the international alliances involving institutionally-distant partners. Our findings therefore support the view that mutual trust is a crucial moderator in the process of international knowledge acquisition, in which the higher level of mutual trust between partners, the less the noxious effects of regulatory and cognitive distances on the firm's access to the knowledge and the more the knowledge would be effectively acquired by the firm. Accordingly, our study offers theoretic explanations on how firms can act to alleviate inherent contextual challenges resulting from regulatory and cognitive distances, and to facilitate their access to the partners' knowledge bases by developing mutual trust along with international collaborations.

\section{Managerial relevance}

This study explains that the complexity and uncertainty of knowledge acquisition across national boundaries mainly result from institutional distance between partner firms and suggests that such contextual challenges can be alleviated by firms if they proactively build up a trustworthy relationship in international business exchanges. We advocate that alliance managers should recognize the role of institutional distance as two sides of a coin while engaging in international knowledge acquisition. Though institutional distance may provide potential learning opportunities for firms to engage in international collaborations, our findings are indicative of the negative association between institutional distance and knowledge acquisition processes.

In particular, firms will more easily undergo arduousness in accessing their partners' knowledge and have trouble understanding the usefulness and causal effects of the transferred knowledge if there are considerable differences in their regulatory and cognitive institutional environments. Consequently, given the eagerness of learning from partners, the learning outcomes with respect to the levels of knowledge acquisition will be unsatisfactory in the institutionally-distant relationships. Nonetheless, we recommend that alliance managers should appreciate the relational investment in international collaborations, especially when learning is the main cooperative objective of the alliance. This is because international knowledge acquisition is found to be enhanced by a trustworthy relationship between partner firms, irrespective of the inherent institutionally-distant challenges in the collaborations.

\section{Limitations and future research directions}

This study presents a number of limitations, the most salient of which is the geographic focus. Our sample may be representative of the population of international business exchange relationships in ICT industries in Taiwan; however, it is not necessarily representative of all Asian countries and is certainly not representative of all countries. Given over 29 countries of origin of the foreign partners surveyed in this study, the scales of institutional distance compared between foreign partners and Taiwanese partners may not produce generalized results. Additionally, the execution of survey research is only dependent on the one-sided perspective, that is, the Taiwanese ICT manufacturers' judgements about the cooperation with foreign partners. Data collected from matched samples of international collaborations would be more preferable and 
balanced; notwithstanding, the option is not feasible in this research because most firms are not willing or are restricted from disclosing their partners' information due to confidentiality.

Open Access This article is distributed under the terms of the Creative Commons Attribution 4.0 International License (http://creativecommons.org/licenses/by/4.0/), which permits unrestricted use, distribution, and reproduction in any medium, provided you give appropriate credit to the original author(s) and the source, provide a link to the Creative Commons license, and indicate if changes were made.

\section{References}

Adler, P. S. 2001. Market, hierarchy, and trust: The knowledge economy and the future of capitalism. Organization Science, 12(2): 215-234.

Bagozzi, R. P., \& Phillips, L. W. 1982. Representing and testing organizational theories: A holistic construal. Administrative Science Quarterly, 27(3): 459-489.

Baughn, C., Denekamp, J., Stevens, J., \& Osborn, R. 1997. Protecting intellectual capital in international alliances. Journal of World Business, 2(2): 103-117.

Baum, J. A. C., \& Oliver, C. 1991. Institutional linkages and organizational mortality. Administrative Science Quarterly, 36: 187-218.

Boersma, M., Buckley, P. J., \& Ghauri, P. N. 2003. Towards a model of trust in international joint venture relationships. Journal of Business Research, 56: 1031-1042.

Brunetto, Y., \& Farr-Wharton, R. 2007. The moderating role of trust in SME owner/managers' decisionmaking about collaboration. Journal of Small Business Management, 45(3): 362-387.

Chao, M. C.-H., \& Kumar, V. 2010. The impact of institutional distance on the international diversityperformance relationship. Journal of World Business, 45(1): 93-103.

Chiang, M.-H. 2012. Taiwan's information and communication technology industry. East Asian Institute background brief no. 751, National University of Singapore.

Cousins, P. D., Handfield, R. B., Lawson, B., \& Petersen, K. J. 2006. Creating supply chain relational capital: The impact of formal and informal socialization processes. Journal of Operations Management, 24: 851863.

Cummings, J. L., \& Teng, B.-S. 2003. Transferring R\&D knowledge: The key factors affecting knowledge transfer success. Journal of Engineering and Technology Management, 20: 39-68.

Dahl, A., \& Lopez-Claros, A. 2006. The impact of information and communication technologies on the economic competitiveness and social development of Taiwan. Geneva: World Economic Forum.

Dikova, D., Sahib, P. R., \& van Witteloostuijn, A. 2010. Cross-border acquisition abandonment and completion: The effect of institutional differences and organizational learning in the international business service industry, 1981-2001. Journal of International Business Studies, 41: 223-245.

Dillman, D. A., Smyth, J. D., \& Christian, L. M. 2009. Internet, mail, and mixed-mode surveys: The tailored design method. Hoboken: John Wiley and Sons.

DiMaggio, P. J., \& Powell, W. W. 1983. The iron cage revisited: Institutional isomorphism and collective rationality in organizational fields. American Sociological Review, 48: 147-160.

Ding, X.-H., Huang, R.-H., \& Liu, D.-L. 2012. Resource allocation for open and hidden learning in learning alliances. Asia Pacific Journal of Management, 29(1): 103-127.

Dutta, S., \& Mia, I. 2011. The global information technology report 2010-2011. Geneva: World Economic Forum and INSEAD.

Dyer, J. H., \& Singh, H. 1998. The relational view: Cooperative strategy and sources of interorganizational competitive advantage. Academy of Management Review, 23(4): 660-679.

Edwards, J. R., \& Lambert, L. S. 2007. Methods for integrating moderation and mediation: A general analytical framework using moderated path analysis. Psychological Methods, 12: 1-22.

Gaur, A. S., \& Lu, J. W. 2007. Ownership strategies and survival of foreign subsidiaries: Impacts of international distance and experience. Journal of Management, 33: 84-110.

Gomes, E., Barnes, B. R., \& Mahmood, T. 2016. A 22 year review of strategic alliance research in the leading management journals. International Business Review, 25(1): 15-27.

Gulati, R. 1995. Does familiarity breed trust? The implications of repeated ties for contractual choice in alliances. Academy of Management Journal, 38: 85-112. 
Hamel, G. 1991. Competition for competence and inter-partner learning within international strategic alliances. Strategic Management Journal, 12: 83-103.

Hamel, G., Doz, Y. L., \& Prahalad, C. K. 1989. Collaborate with your competitors and win. Harvard Business Review, 67(1): 133-139.

Hayes, A. F. 2013. Introduction to mediation, moderation, and conditional process analysis: A regressionbased approach. New York: Guilford Press.

Hofstede, G. 2011. Dimensions of national culltures: http:/www.geerthofstede.nl/culture/dimensions-ofnational-cultures.aspx. Accessed 7 June 2011.

Huber, G. P. 1991. Organizational learning: The contributing processes and the literatures. Organization Science, 2(1): 88-115.

Ingram, P., \& Silverman, B. S. 2002. The new institutionalism in strategic management: Advances in strategic management. Greenwich: JAI Press.

Inkpen, A. C. 2000. Learning through joint ventures: A framework of knowledge acquisition. Journal of Management Studies, 37(7): 1019-1043.

Inkpen, A. C. 2008. Strategic alliances. In A. M. Rugman (Ed.). The Oxford handbook of international business: 389-416. New York: Oxford University Press.

Inkpen, A. C., \& Beamish, P. W. 1997. Knowledge, bargaining power, and the instability of international joint ventures. Academy of Management Review, 22(1): 177-202.

Ionascu, D., Meyer, K. E., and Erstin, S. 2004. Institutional distance and international business strategies in emerging economies. William Davidson Institute working paper no. 728, University of Michigan Business School.

Javidan, M., Stahl, G. K., Brodbeck, F., \& Wilderom, C. P. M. 2005. Cross-border transfer of knowledge: Cultural lessons from project GLOBE. Academy of Management Executive, 19(2): 59-76.

Jensen, J. J. P., van den Bosch, F. A. J., \& Volberda, H. W. 2005. Managing potential and realized absorptive capacity: How do organizational antecedents matter?. Research paper no. ERS-2005-025-STR, Erasmus Research Institute of Management.

Johanson, J., \& Vahlne, J.-E. 2009. The Uppsala internationalization process model revisited: From liability of foreignness to liability of outsidership. Journal of International Business Studies, 40: 1411-1431.

Khanna, T., Gulati, R., \& Nohria, N. 1998. The dynamics of learning alliances: Competition, cooperation, and relative scope. Strategic Management Journal, 19(3): 193-210.

King, A. W., \& Zeithaml, C. P. 2001. Competencies and firm performance: Examining the causal ambiguity paradox. Strategic Management Journal, 22: 75-99.

Ko, D.-G., Kirsch, L. J., \& King, W. R. 2005. Antecedents of knowledge transfer from consultants to clients in enterprise system implementations. MIS Quarterly, 29(1): 59-85.

Kogut, B., \& Singh, H. 1988. The effect of national culture on the choice of entry mode. Journal of International Business Studies, 19: 411-432.

Kogut, B., \& Zander, U. 1992. Knowledge of the firm, combinative capabilities, and the replication of technology. Organization Science, 3(3): 383-397.

Kostova, T. 1996. Success of the transnational transfer of organizational practices within multinational companies. Unpublished $\mathrm{PhD}$ Thesis, University of Minnesota.

Kwan, M. M., \& Cheung, P.-K. 2006. The knowledge transfer process: From field studies to technology development. Journal of Database Management, 17(1): 16-32.

Lane, P. J., Salk, J. E., \& Lyles, M. A. 2001. Absorptive capacity, learning, and performance in international joint ventures. Strategic Management Journal, 22: 1139-1161.

Larsson, A. 1992. Network dyads in entrepreneurial settings: A study of the governance of exchange relationships. Administrative Science Quarterly, 37(1): 76-104.

Lee, S.-C., Chang, S.-N., Liu, C. Y., \& Yang, J. 2007. The effect of knowledge protection, knowledge ambiguity, and relational capital on alliance performance. Knowledge and Process Management, 14(1): 58-69.

Li, D., \& Ferreira, M. P. 2008. Partner selection for international strategic alliances in emerging economies. Scandinavian Journal of Management, 24: 308-319.

Li, S., \& Scullion, H. 2006. Bridging the distance: Managing cross-border knowledge holders. Asia Pacific Journal of Management, 23(1): 71-92.

Liu, C.-L.(E.)., Ghauri, P. N., \& Sinkovics, R. R. 2010. Understanding the impact of relational capital and organizational learning on alliance outcomes. Journal of World Business, 45(3): 237-249.

Liu, X., \& Giroud, A. 2016. International knowledge flows in the context of emerging-economy MNEs and increasing global mobility. International Business Review, 25(1): 125-129.

Lyles, M. A., \& Salk, J. E. 1996. Knowledge acquisition from foreign parents in international joint ventures. Journal of International Business Studies, 27: 905-927. 
Manev, I. M., \& Stevenson, W. B. 2001. Nationality, cultural distance, and expatriate status: Effects on the managerial network in a multinational enterprise. Journal of International Business Studies, 32(2): 285303.

March, J. 1981. Decisions in organizations and theories of choice. In A. Van de Ven, \& W. Joyce (Eds.). Perspectives on organizational design and behavior. New York: Wiley.

Mayer, R. C., Davis, J. H., \& Schoorman, F. D. 1995. An integrative model of organizational trust. Academy of Management Review, 250: 709-734.

McEvily, S. K., Das, S., \& McCabe, K. 2000. Avoiding competence substitution through knowledge sharing. Academy of Management Review, 25(2): 294-311.

Morosini, P., Shane, S., \& Singh, H. 1998. National cultural distance and cross-border acquisition performance. Journal of International Business Studies, 29(1): 137-158.

Muthusamy, S. K., \& White, M. A. 2005. Learning and knowledge transfer in strategic alliances: A social exchange view. Organization Studies, 26(3): 415-441.

Narteh, B. 2008. Knowledge transfer in developed-developing country interfirm collaborations: A conceptual framework. Journal of Knowledge Management, 12(1): 78-91.

Nguyen, T. V., Weinstein, M., \& Meyer, A. D. 2005. Development of trust: A study of interfirm relationships in Vietnam. Asia Pacific Journal of Management, 22(3): 211-235.

Nielsen, B. B. 2005. The role of knowledge embeddedness in the creation of synergies in strategic alliances. Journal of Business Research, 58: 1194-1204.

Nielsen, B. B., \& Nielsen, S. 2009. Learning and innovation in international strategic alliances: An empirical test of the role of trust and tacitness. Journal of Management Studies, 46(6): 1031-1056.

Nonaka, I., \& Takeuchi, H. 1995. The knowledge-creating company. New York: Oxford University Press.

Nooteboom, B., Van Haverbeke, W., Duysters, G., Gilsing, V., \& Van den Oord, A. 2007. Optimal cognitive distance and absorptive capacity. Research Policy, 36: 1016-1034.

Norman, P. M. 2002. Protecting knowledge in strategic alliances: Resources and relational characteristics. Journal of High Technology Management Research, 13: 177-202.

North, D. C. 1990. Institutions, institutional change and economic performance. Cambridge: Cambridge University Press.

Park, B. I. 2008. What matters to managerial knowledge acquisition in international joint ventures? High knowledge acquirers versus low knowledge acquirers. Asia Pacific Journal of Management, 27(1): 5579.

Park, B. I., \& Ghauri, P. N. 2011. Key factors affecting acquisition of technological capabilities from foreign acquiring firms by small and medium sized local firms. Journal of World Business, 46(1): 116-125.

Park, B. I., Giroud, A., Mirza, H., \& Whitelock, J. 2008. Knowledge acquisition and performance: The role of foreign partners in Korean IJVs. Asian Business and Management, 7: 11-32.

Peltokorpi, V. 2017. Absorptive capacity in foreign subsidiaries: The effects of language sensitive recruitment, language training, and interunit knowledge transfer. International Business Review, 26(1): 119-129.

Peng, M. W., Sun, S. L., Pinkham, B. C., \& Chen, H. 2009. The institution-based view as a third leg for a strategy tripod. Academy of Management Perspectives, 23(3): 63-81.

Polanyi, M. 1966. The logic of tacit inference. Journal of the Royal Institute of Philosophy, 41(155): 1-18.

Porras, S. T., Clegg, S., \& Crawford, J. 2004. Trust as networking knowledge: Precedents from Australia. Asia Pacific Journal of Management, 21(3): 345-363.

Puffer, S. M., McCarthy, D. J., Jaeger, A. M., \& Dunlap, D. 2013. The use of favors by emerging market managers: Facilitator or inhibitor of international expansion?. Asia Pacific Journal of Management, 30(2): 327-349.

Quintas, P., Lefrere, P., \& Jones, G. 1997. Knowledge management: A strategic agenda. Long Range Planning, 30: 385-391.

Ring, P. S., \& Van de Ven, A. H. 1994. Developmental processes of cooperative interorganizational relationships. Academy of Management Review, 19(1): 90-118.

Sako, M. 1998. Does trust improve business performance?. Oxford: Oxford University Press.

Sarala, R. M., \& Vaara, E. 2010. Cultural differences, convergence, and crossvergence as explanations of knowledge transfer in international acquisitions. Journal of International Business Studies, 41: 13651390.

Scott, W. R., \& Meyer, J. W. 1994. Institutional environments and organizations: Structural complexity and individualism. London: Sage.

Shrout, P. E., \& Bolger, N. 2002. Mediation in experimental and nonexperimental studies: New procedures and recommendations. Psychological Methods, 7(4): 422-445.

Simonin, B. L. 1999a. Ambiguity and the process of knowledge transfer in strategic alliances. Strategic Management Journal, 20: 595-623. 
Simonin, B. L. 1999b. Transfer of marketing know-how in international strategic alliances: An empirical investigation of the role and antecedents of knowledge ambiguity. Journal of International Business Studies, 30(3): 463-490.

Simonin, B. L. 2004. An empirical investigation of the process of knowledge transfer in international strategic alliances. Journal of International Business Studies, 35(5): 401-427.

Svejenova, S. 2006. How much does trust really matter? Some reflections on the significance and implications of Madhok's trust-trust based approach. Journal of International Business Studies, 37(1): 12-20.

Tihanyi, L., Griffith, D. A., \& Russell, C. J. 2005. The effect of cultural distance on entry mode choice, international diversification, and MNE performance: A meta-analysis. Journal of International Business Studies, 36(3): 270-283.

Tsang, E. W. K. 1999. A preliminary typology of learning in international strategic alliances. Journal of World Business, 34(3): 211-229.

Tsang, E. W. K., Nguyen, D. T., \& Erramilli, M. K. 2004. Knowledge acquisition and performance of international joint ventures in the transition economy of Vietnam. Journal of International Marketing, 2: 82-103.

Van Wijk, R., Jansen, J. J. P., \& Lyles, M. A. 2008. Inter- and intra-organizational knowledge transfer: A metaanalytic review and assessment of its antecedents and consequences. Journal of Management Studies, 45(4): 830-853.

Wang, C. C., \& Wu, A. 2016. Geographical FDI knowledge spillover and innovation of indigenous firms in China. International Business Review, 25(4): 895-906.

William, C., \& Lee, S. H. 2016. Knowledge flows in emerging market MNC - The role of subsidiary HRM practices in Korean MNCs. International Business Review, 25(1): 233-243.

Williams, C., \& Du, J. 2014. The impact of trust and local learning on the innovative performance of MNE subsidiaries in China. Asia Pacific Journal of Management, 31(4): 973-996.

Williamson, O. 1993. Calculativeness, trust and economic organization. Journal of Law and Economics, 36: 453-486.

$\mathrm{Xu}, \mathrm{K}$. , Huang, K.-F., \& Gao, S. 2010. The effect of institutional ties on knowledge acquisition in uncertain environments. Asia Pacific Journal of Management, 29(2): 387-408.

Yiu, D., \& Makino, S. 2002. The choice between joint venture and wholly owned subsidiary: An institutional perspective. Organization Science, 13(6): 667-683.

Yli-Renko, H., Autio, E., \& Sapienza, H. J. 2001. Social capital, knowledge acquisitions, and knowledge exploitation in young technology-based firms. Strategic Management Journal, 22: 587-613.

Mia Hsiao-Wen Ho (PhD, King's College London, UK) is an Assistant Professor of business management at National Sun Yat-sen University in Taiwan. Her research focuses on the co-evolution of international strategic alliances, cross-border knowledge transfer and learning processes, and the internationalization strategies of emerging market multinationals.

Pervez N. Ghauri (PhD, Uppsala University, Sweden) is Professor of international business, at University of Birmingham, UK. His research focuses on strategies of multinational enterprises (MNEs), emerging markets and the role of MNEs on local development in emerging markets. He has published in journal such as the Journal of International Business Studies, Journal of World Business, Management International Review, Asia Pacific Journal of Management, and International Management Review. He is Editor-in- Chief for International Business Review.

Jorma A. Larimo ( $\mathrm{PhD}$, University of Vaasa, Finland) is Professor of international business, at the University of Vaasa, Finland. He is currently also the Dean of the Faculty of Business Studies. His research focuses on internationalization and international marketing strategies of SMEs as well as on international acquisition and joint venture strategies, performance and divestments. He has published in journals such as the International Business Review, Journal of International Business Studies, Journal of International Management, Journal of World Business, and Management International Review. 